\title{
A challenging treatment of an 18 th century embroidered textile using gel cleaning in combination with decamethylcyclopentasiloxane (D5) silicone solvent barriers
}

\author{
Anja Smets ${ }^{1, *}$ \\ Kristel De Vis ${ }^{2}$ \\ Natalie Ortega-Saez ${ }^{2}$ \\ ${ }^{1}$ Freelance textile conservator, Antwerp, Belgium \\ ${ }^{2}$ University of Antwerp, Faculty of Design Sciences, Conservation Studies, Blindestraat 9, 2000 Antwerp, \\ Belgium \\ *anjasmets@live.be
}

\section{Abstract}

Bleeding dyes are a major concern to textile conservators; they can cause extensive damage to textile objects and usually preclude a wet cleaning treatment. Since gel cleaning methods were introduced to the conservation field, new opportunities are available for such complex treatments. This paper describes the cleaning of an embroidered textile that is damaged by dye bleeding of the embroidery threads on an undyed silk ground. It was examined whether further bleeding of the dyes during wet cleaning can be avoided by the use of an agarose gel to deliver an aqueous solution, prepared with $\mathrm{pH}$ buffers and chelators, to the silk ground. Additionally, the siloxanes octamethylcyclotetrasiloxane (D4) and decamethylcyclopentasiloxane (D5) were tested for their potential to act as barrier liquids for the embroidered areas. The cleaning method was successful in preventing further bleeding of the dyes, but the coloured stains could not be removed completely by the compound cleaning solution. Further research is required to optimize the cleaning method.

O difícil tratamento de um bordado do século XVIII com

gel de limpeza em combinação com barreira de líquido

de silicone decametilciclopentasiloxano (D5)

\section{Resumo}

A migração de corantes é um problema para os conservadores de têxteis, pois pode causar danos significativos nos objectos e impedir o seu tratamento por via húmida. Com a introdução dos geles de limpeza em conservação, surgiram novas oportunidades para esses tratamentos difíceis. Este artigo descreve a limpeza de uma peça de seda danificada devido à migração de corantes dos fios do bordado para o fundo branco. Investigámos se, através do uso de gel de agarose com uma solução aquosa preparada com soluções-tampão de pH e quelantes, pode ser evitada a continuação da migração dos corantes durante o tratamento por via húmida. As soluções de siloxanos octametilciclotetrasiloxano (D4) e decametilciclopentasiloxano (D5) foram também testadas devido à possibilidade do seu uso, como barreiras de líquido, para protecção do bordado. O método de limpeza desenvolvido foi eficaz na prevenção da continuação da migração dos corantes, mas as manchas iniciais não puderam ser removidas completamente. É necessária investigação adicional com vista à optimização deste método.

\section{Keywords}

Textile conservation

Bleeding dyes

Gel cleaning

Agarose

D4 and D5 silicone solvents

\section{Palavras-chave}

Conservação de têxteis

Migração de corantes

Gel de limpeza

Agarose

Solventes de silicone D4 e D5 


\section{Introduction}

In 2016, the textile collection of Hotel-Museum Merghelynck in Ypres (Belgium) was transferred to the conservation department of the University of Antwerp for conservation treatment. One of the objects in the collection was a textile embroidered with floral motifs. The object was in poor aesthetic condition, presenting a yellowed ground, folds in the object, a wrinkled surface and in particular stains of dye bleed. The damage present indicated that the textile had been stored in a humid environment for a long time or had become wet during a possible calamity (Figure 1).

Stains caused by dye bleeding not only disfigure the textile, but also pose a potential risk of damage and further degradation of the textile fibres. Acidic or alkaline components of coloured organic substances can affect degradation processes. Possible residual products from the dye process containing metal ions (e.g. $\mathrm{Fe}, \mathrm{Cu}, \mathrm{Al}$ ) could also be present in the stains, where they could instigate various degradation processes including the photo-oxidation of textile fibres when exposed to visible and ultraviolet light [1]. In order to conserve the textile, cleaning was necessary.

The colourfastness of the embroidery threads in an aqueous environment was first tested. Seventeen samples were taken, of which fifteen were removed from different areas in the silk embroidery and two from the metal- thread embroidery. The results of this test clearly indicated that the dyes of all the threads are water-sensitive.

These results made it challenging to find a suitable and safe cleaning method. Because of the risk of dye bleeding and additional damage to the textile, it was necessary to search for a cleaning method that did not render the embroidery threads wet.

Inspired by the successful cleaning of an embroidered sampler with a similar conservation issue, gel cleaning was examined as a potential treatment method for the embroidered textile. By analogy with the cleaning by Sahmel et al., it was investigated whether a cleaning solution could be composed with chelating agents and $\mathrm{pH}$ buffers to remove or reduce the dye bleed on the textile. In addition, agarose gel was tested as a potentially suitable medium for applying the cleaning solution on the silk ground between the embroidery. On the suggestion of Prof. Richard Wolbers, the siloxanes D4 and D5 replaced the cyclododecane used by Sahmel et al. to protect the embroidery against further bleeding of the dyes [2].

\section{The object}

\section{Original materials and techniques}

Identification of the materials and techniques used in the object was performed with polarized light microscopy

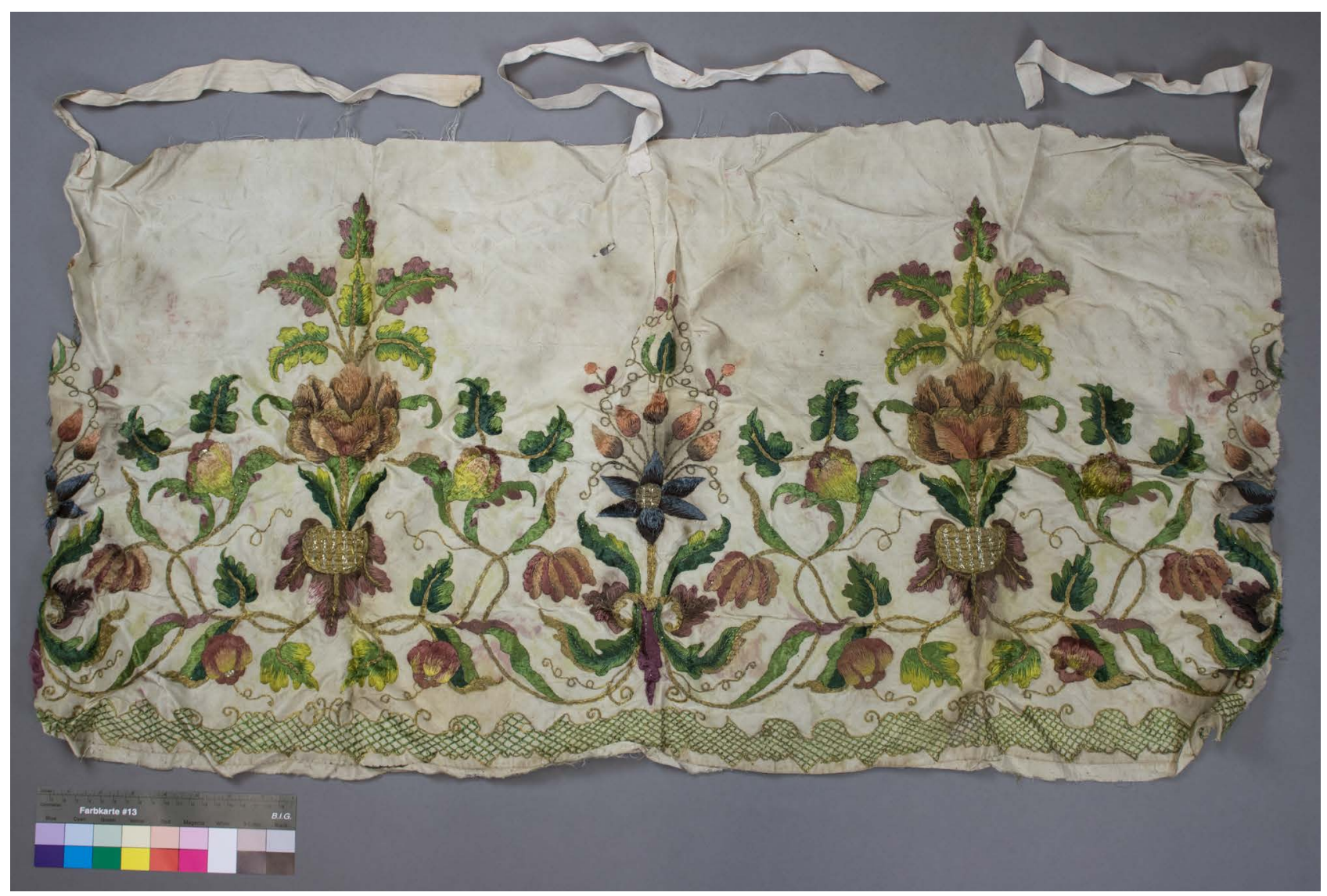

Figure 1. Embroidered textile in the collection of Hotel-Museum Merghelynck (Ypres, Belgium), before treatment. 
(PLM MOTIC BA310Pol) and stereo microscopy (NEOC T1A 250V).

The embroidery is applied on a fine plain-woven silk ground $(52.5 \mathrm{~cm}$ height $\times 101 \mathrm{~cm}$ width) with 30 warp threads/cm and 40 weft threads $/ \mathrm{cm}$. The silk ground is not dyed and no after-treatment (like starch) could be traced under magnification.

A pattern of flowers and leaves is applied on the ground by silk embroidery and metal-thread embroidery. At the bottom a more abstract border is embroidered in a chequered pattern by couching (lattice couching), framed by metal-thread embroidery.

Fifteen different colours of embroidery thread are used to create the silk embroidery pattern with satin stitches and shadow stitches. Analysis of the dyes was not performed, but it is likely that the embroidery threads are dyed with natural dyes because the textile has been tentatively dated to the eighteenth century. For the metalthread embroidery two types of metal-thread are used: solid metal strips and metal strips wound around a silk core have been applied by couching to form flower hearts, leaf grains and petioles.

\section{Condition}

The silk ground is in a relatively good structural condition. It is slightly yellowed by natural degradation processes; however, the silk has not become brittle. In some areas cracks are present along the edges of embroidered forms and the metal-thread embroidery, probably as a result of the many stitching holes that have weakened the silk fabric.

The main damage is caused by the object having been exposed to moisture. As a result, the dyes of the embroidery threads have run out on the silk ground and the embroidery has lost its initial brightness. Moreover, the object was stored poorly and folded in an inappropriate way. This has caused several folds in the object and some embroidered figures have left a print on the silk ground. Moisture has also caused corrosion and degradation of the metal-threads, with loss of many threads, deposits of copper salts and discolouration of the silk embroidery beneath (Figure 2).

\section{Testing for treatment - materials and methods}

The gel cleaning method with aqueous cleaning solutions consists of two fundamental concepts: on the one hand adding a gelling agent to a cleaning solution to increase the viscosity and thereby gain better control over the cleaning solution during application on a surface, on the other hand optimization of the cleaning capacity of water by the addition of chelating agents, $\mathrm{pH}$ buffers, and/or enzymes or surfactants [3].

As a result, different cleaning parameters are involved. In order to define these parameters, the testing procedure


Figure 2. a) Condition of the object before treatment, showing stains of dye bleed on the silk ground of the textile, a wrinkled surface and folds in the textile. b) Some embroidered figures have left a print of dye bleed on the silk ground.

was divided in two parts. The first part concerns the physical action of the cleaning process, which aims to deliver a cleaning solution to the silk ground of the embroidered textile while avoiding contact with the water-sensitive dyes of the embroidery threads. Agarose was chosen as gelling agent because the agarose gel can be easily cut to fit in between the embroidered areas. Additionally, the siloxanes D4 and D5 were tested for their capacity to form a barrier between the cleaning solution and the embroidery threads. The second part of the testing procedure concerns the chemical aspect of stain removal, and aims to compose a cleaning solution effective in reducing the stains of the dye bleed. In this study, the additives were limited to a $\mathrm{pH}$ buffer and a chelating agent.

The materials are briefly explained in the following subsections, followed by a detailed discussion of the test procedure.

\section{Agarose gel}

Agarose is a polysaccharide derived from red seaweed Gelidium. Agarose gel is prepared by dispersing agarose in powder form in an aqueous solution and heating to a 

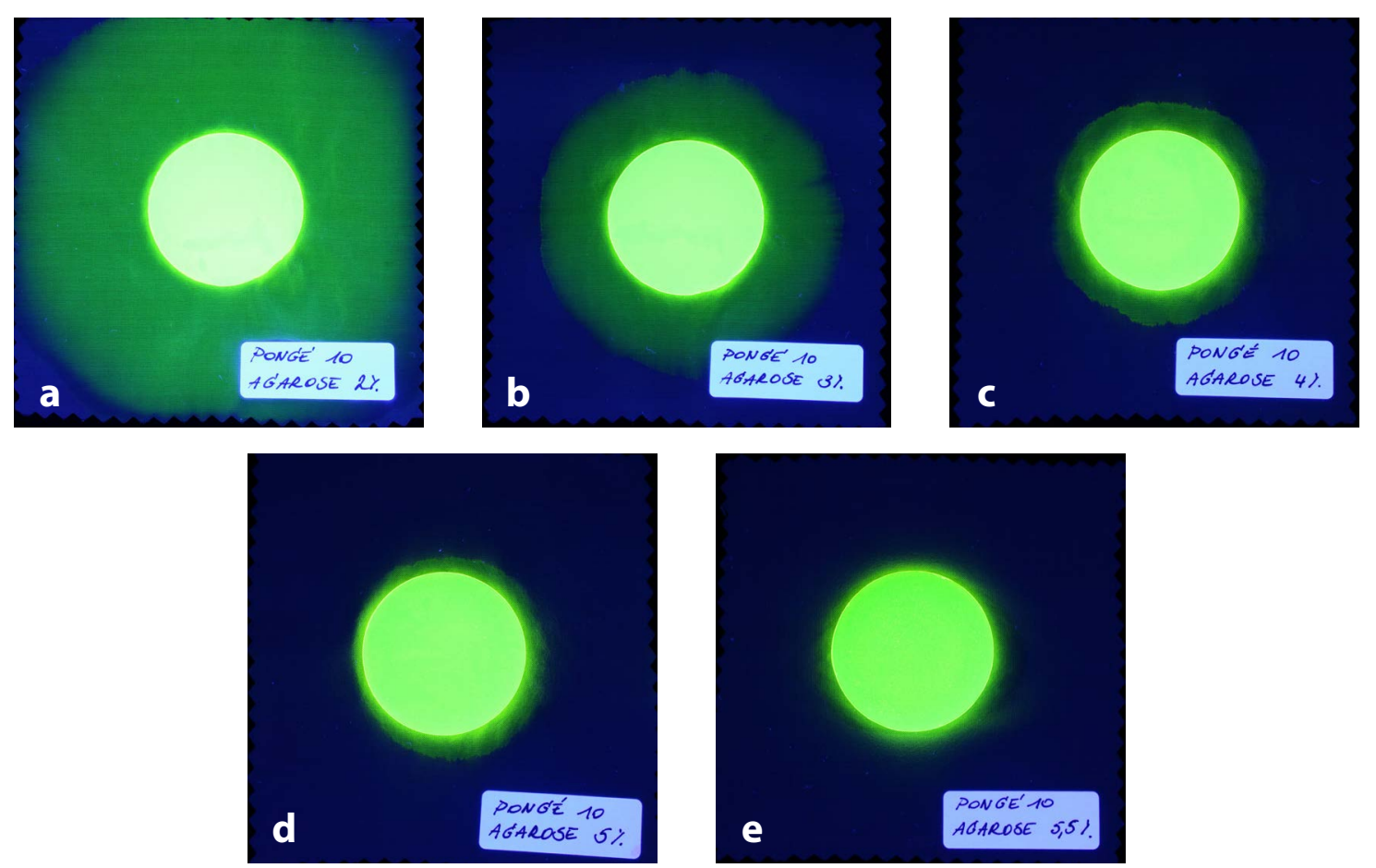

Figure 3. Evaluation of the spreading of a solution into a pongé 10 silk test substrate. agarose gel pads were prepared with the same size and thickness in increasing concentration: $a) 2 \%(\mathrm{~m} / \mathrm{v})$ gel; $b) 3 \%(\mathrm{~m} / \mathrm{v})$ gel; $c$ ) $4 \%(\mathrm{~m} / \mathrm{v})$ gel; $d) 5 \%(\mathrm{~m} / \mathrm{v})$ gel; $e) 5.5 \%(\mathrm{~m} / \mathrm{v})$ gel. The fluorescent dye uranine $(0.02 \mathrm{~g} / \mathrm{l})$ was added to the solution to visualise the spread under UV illumination.

temperature above $85{ }^{\circ} \mathrm{C}$. Upon cooling, gel formation takes place at a temperature of $37-39^{\circ} \mathrm{C}$. Agarose forms a gel at low concentrations of mass per volume percentage $(\mathrm{m} / \mathrm{v})$. Usually concentrations between $2 \%$ and $5 \%(\mathrm{~m} / \mathrm{v})$ are used, depending on the method of application and the water sensitivity of the object to be treated [4].

The porous structure of the agarose gel facilitates a slow diffusion of liquids by capillary action. The absorption rate of the gel can be manipulated by changing the concentration of agarose in the solution. At higher concentrations the pores are smaller and the capillary action is stronger; at lower concentrations, the effect is the opposite. [5].

The gel is non-ionic and can be used within a $\mathrm{pH}$ range from 4.5 to 10. After preparation the agarose gel is transparent, which allows continuous observation during treatment [2]. An additional advantage to the use of a rigid gel like agarose gel is that it does not require extensive clearing procedures. The gel is in no way attached to the surface and can easily be removed without leaving a visible trace [4-5].

The concentration of the gel $(\mathrm{m} / \mathrm{v})$ and the thickness of the gel pad can be directly related to the distribution of the cleaning solution into a textile. Agarose gels prepared at a low gellant concentration show better contact with textile texture and have a positive influence on the diffusion process and capillary action during the cleaning process. However, low-concentration gels have larger pores and consequently a weaker capillary action, allowing the solution to spread quickly through the textile. The spread is also dependent on the weaving structure, the fibre type and the surface tension of the textile fibres [6].

To evaluate how the cleaning solution will move through the silk ground of the embroidered textile, pongé 10 natural silk was selected as a test substrate since it is most alike in structure to the silk ground of the object to be treated. Pongé 10 is plain-woven and has an equal number of warp and weft threads per centimetre. Before testing, the substrate was pre-washed in demineralised water for 30 minutes at $60{ }^{\circ} \mathrm{C}$ to remove any post-treatments. Agarose gels (Molecular Biology Grade) were prepared in increasing concentrations $(\mathrm{m} / \mathrm{v})$. The gel pads were made with the same size $(\varnothing 4 \mathrm{~cm})$ and thickness $(3 \mathrm{~mm})$, so that only the concentration of the gel was a variable. To visualize the distribution of the cleaning solution into the textile, the fluorescent dye uranine was added to the solution $(0.02 \mathrm{~g} / \mathrm{l})$. Uranine (CAS No. 518-47-8) is a yellow-green fluorescent water-soluble dye and can be used as an indicator in the detection of water flows, such as in leak tests of walls, pipes and tanks; fluorescence can already be observed well at low concentrations with UV light (black light) [7]. The gel pads were photographed after 30 minutes on the substrate in a dark room with ultraviolet illumination (Figure 3).

The tests show that the halo encircling the gel pad decreases, and consequently the spreading of the solution in the textile decreases, as the concentration of agarose in the solution increased. At least a $5 \%(\mathrm{~m} / \mathrm{v})$ gel is necessary to contain the solution within the circumference of the gel pad, with a slightly better result at a $5.5 \%(\mathrm{~m} / \mathrm{v})$ gel. The fluorescence visible at these concentrations around the 
gel pad is mainly a reflection of the gel pad itself. Testing at higher concentrations did not yield better results.

The rigidity of the gel pad increased considerably as the concentration of agarose was increased, which hindered a good contact of the gel with the substrate. Even on the new and flat pongé silk test fabric, a $5 \%(\mathrm{~m} / \mathrm{v})$ gel or $5.5 \%(\mathrm{~m} / \mathrm{v})$ gel showed poor contact with the substrate. The contact could be improved by placing a small weight (for example a glass plate) on the gel pad.

In order to prevent contact of the cleaning solution with the embroidery threads, a $5 \%(\mathrm{~m} / \mathrm{v})$ gel was chosen to clean the silk ground between the embroidery.

\section{D4/D5 silicone solvents as barriers}

Predicting the spread of the cleaning solution when working on the natural aged silk ground of the embroidered textile remained difficult. As any contact of the cleaning solution with the embroidery must be avoided, further testing was carried out with the siloxanes D4 and D5 for their potential to act as barrier liquids.
D4 (octamethylcyclotetrasiloxane) and D5 (decamethylcyclopentasiloxane) are volatile cyclic siloxanes, commercially known as cyclomethicones. A few years ago, these products were introduced in the conservation field when Richard Wolbers started using silicon-based solvents to make micro-emulsions for cleaning acrylic painted surfaces [8]. These organic solvents have been used for the first time in the dry-cleaning industry in response to legal and social pressure to go-green (to use environmental and human-friendly solvents). In textile conservation research into the potential of D5 as an alternative solvent for textile conservation cleaning was also carried out [9]. In paper conservation D4 was examined as a masking agent during local aqueous treatment of paper objects [10].

D4 and D5 both are extremely non-polar. The solvents have a low surface tension and therefore spread easily on porous and non-porous surfaces [10]. The high molecular mass of D4 (MW $296.62 \mathrm{~g} / \mathrm{mol}$ ) and D5 (MW $370.77 \mathrm{~g} / \mathrm{mol}$ ) promotes a slow evaporation rate of the solvents [11-12]. Exact evaporation rates when applied on textiles are not
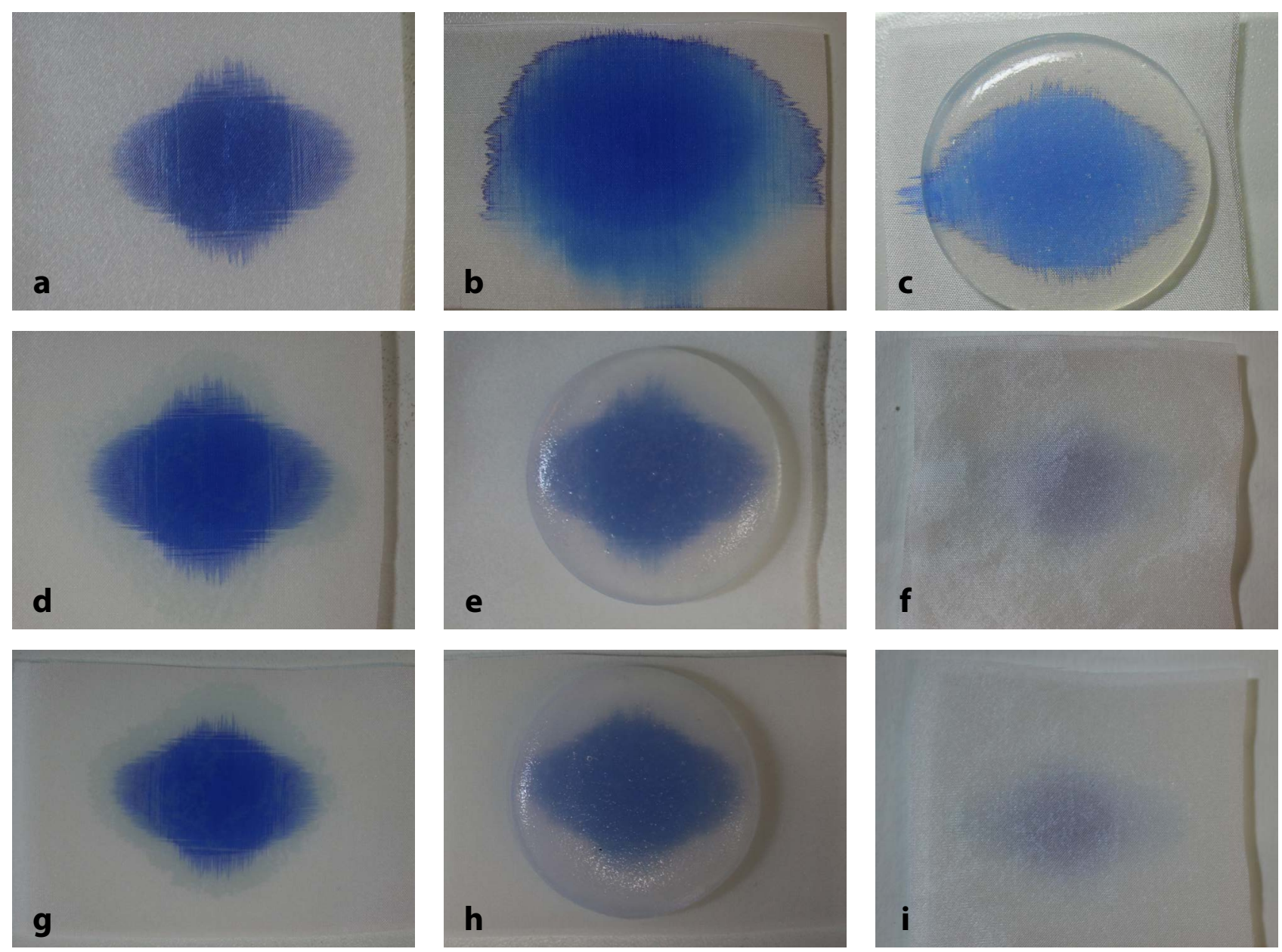

Figure 4. Initial experiments with D4 and D5 to establish their working properties on a pongé 10 silk substrate. $a$ ) Reference sample with ink stain. $b$ ) Wetting the ink stain with a drop of water immediately caused spreading of the ink in the substrate. $c$ ) Application of a $5 \%(\mathrm{~m} / \mathrm{v})$ gel pad to an ink stain immediately caused movement of ink in the substrate beyond the circumference of the gel pad. No migration of ink could be observed when D4 (d) or D5 $(\mathrm{g})$ was applied on the ink stain. 30 minute application of a $5 \%(\mathrm{~m} / \mathrm{v}) \mathrm{gel}$ pad on an ink stain saturated with D4 (e) or D5 (h). After 90 minutes, the $5 \%(\mathrm{~m} / \mathrm{v})$ agarose gel had absorbed the ink almost completely. $f$ ) On the substrate saturated with D4 tidelines were slightly visible. $i$ ) No tidelines were formed when the surface was saturated with D5. 
Table 1

Additional tests on a pongé 10 test substrate to ascertain if D4 or D5 have a supporting function in containing a cleaning solution within the circumference of the gel pad

\begin{tabular}{|c|c|c|c|}
\hline & After 30 minutes & After 60 minutes & After drying \\
\hline $\begin{array}{l}5 \%(\mathrm{~m} / \mathrm{v}) \\
\text { gel substrate } \\
\text { saturated with } \\
\text { D4 }\end{array}$ & & & \\
\hline $\begin{array}{l}5 \%(\mathrm{~m} / \mathrm{v}) \\
\text { gel substrate } \\
\text { saturated with } \\
\text { D5 }\end{array}$ & 8 & & \\
\hline
\end{tabular}

known. D4 has an evaporation rate of about 20 minutes and D5 is completely evaporated after about 2 hours, without leaving visible traces on a textile. The evaporation rate also depends on the ambient temperature and the amount of solvent applied to the surface. The evaporation rate can be controlled by mixing the two solvents [13].

A few experiments on pongé 10 silk with stains of water-soluble blue ink were performed to establish the working properties of the cyclomethicones. Initial tests did not match the expected results. The agarose gel was still able to absorb water-soluble contamination from a surface saturated with D4 or D5 (Figure 4). This observation implies that saturating the embroidery threads with D4 or D5 does not prevent further bleeding of the dyes in the event that the gel accidentally makes contact with the embroidery.

The slower evaporation time of D5 is advantageous as the working-time can be prolonged to 90 minutes. Moreover, no tidelines formed within this time. When D4 was used, tidelines formed, possibly because D4 completely evaporated before the gel could extract the water-soluble substances from the textile.

Initial tests showed that no tidelines were formed when cyclomethicones were used over a working-time shorter than that necessary for their evaporation. There does not seem to be migration of dirt particles outside the gel pad, which occurred when cyclomethicones were not used or when their working-time has exceeded. These findings have led to additional testing to ascertain whether D4 or D5 may have a supporting function in containing a cleaning solution within the circumference of the gel pad.

To visualise the possible supporting function of D4 vs. D5, pieces of pongé 10 silk were completely impregnated with blue water-soluble ink and, after drying, saturated with D4 or D5. A $5 \%(\mathrm{~m} / \mathrm{v})$ agarose gel was placed on the substrates for 60 minutes (Table 1).

Visually, it was established that the absorption of ink through the gel occurs completely within the circumference of the gel pad. More ink was absorbed in the centre than at the edges of the gel pad. Ink absorption was faster when the surface was saturated with D4.

In order to extend the duration of the cleaning, D5 was selected to saturate the surface of the embroidered textile to be cleaned.

\section{Cleaning with pH buffers and chelators}

Aqueous cleaning solutions with buffers and chelators have the potential to dissolve acidic or alkaline substances that are formed during the degradation of organic materials by ionisation and/or dissociation, and solvate insoluble salts by chelation [3].

Buffer solutions always consist of a weak acid (or base) and its conjugate base (or acid). They are characterized by their $\mathrm{pK}_{\mathrm{a}}$ value (acid dissociation constant) [14]. The $\mathrm{pK}_{\mathrm{a}}$ value of a buffer solution expresses the $\mathrm{pH}$ value of the buffer solution. This is also the $\mathrm{pH}$ value at which the buffer is most effective in preventing $\mathrm{pH}$ changes to the cleaning solution when small amounts of acidic or basic components are solubilised from the surface undergoing treatment. A weak acid or a weak base functions as a buffer within about $1 \mathrm{pH}$ unit of its $\mathrm{pK}_{\mathrm{a}}$ value [15] (Figure 5 [16]).

Chelating agents form water-soluble complexes with metal ions and are powerful agents in aqueous solutions used to remove contamination in which metal ions are 
Buffering range

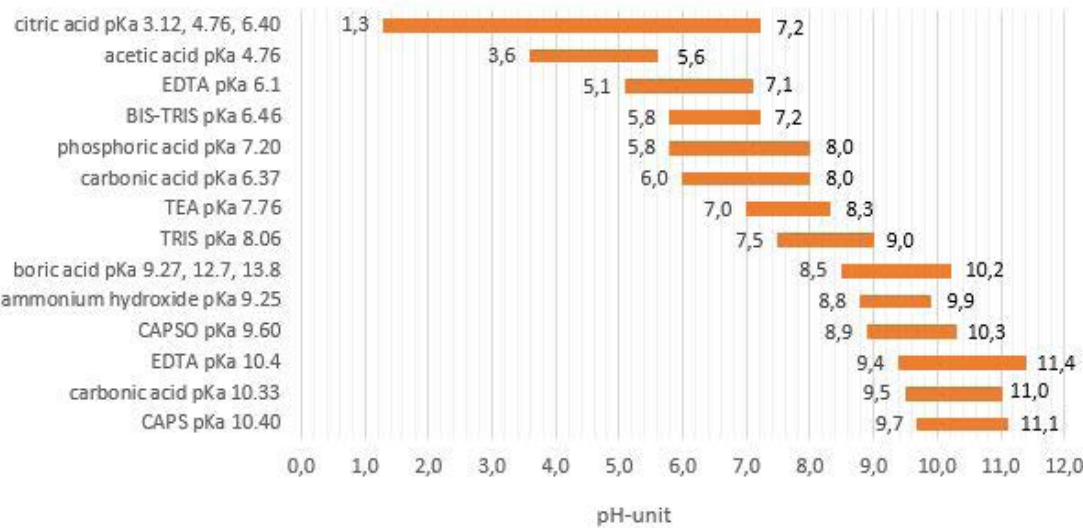

Figure 5. Useful buffering range of various buffers used in conservation [16].

ions (e.g. $\mathrm{Fe}, \mathrm{Cu}, \mathrm{Mn}, \mathrm{Sn}$ ) cannot be cleaned with chelators because chelation can lead to damage and/or loss of the constituent materials. Finally, the textile fibres can be sensitive to the $\mathrm{pH}$ conditions required for effective chelation [1].

Contamination on the silk ground of the embroidered textile consists of a combination of various constituents, such as colouring components of (natural) dyes, residual products of the dyeing process (e.g. metal salts of mordants), corrosion products of the metal threads, and degradation products of the textile and dyes. Consequently, the surface to be cleaned contains a mix of ions (pos-

present [1]. Citric acid, EDTA (ethylenediaminetetraacetic acid) and DTPA (diethylenetriaminepentaacetic acid) are frequently used chelating agents in the conservation field, each with its own affinity for different metal ions [15]. They are most effective when they are fully ionized, which depends highly on the $\mathrm{pH}$ of the solution. The effect of $\mathrm{pH}$ on chelating agents is complex. Since chelators such as citric acid and EDTA also act as buffers, they maintain their initial $\mathrm{pH}$ until the limit of their buffering capacity is reached [1].

There are various limitations regarding the use of chelating agents for cleaning historical textiles. If the $\mathrm{pH}$ is raised above 12, they form insoluble compounds with metal ions and can precipitate on the object. Mordants of dyes may be chelated, resulting in colour change or bleeding of dyes. Inorganic agents such as tin salts used for the weighting of silk can be extracted from the silk when chelators are used. Textiles coloured, painted or printed with inorganic agents or with pigments containing metal

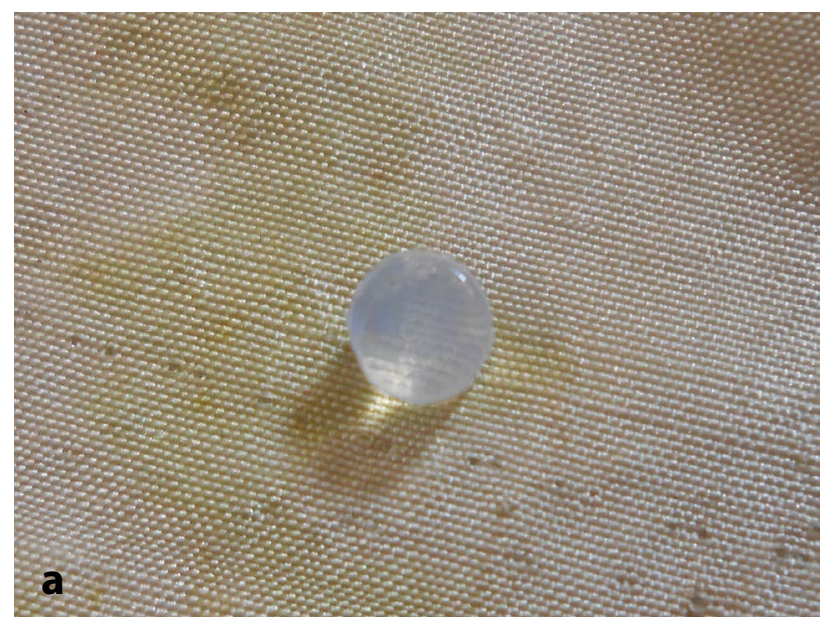

Figure 6. a) Surface $\mathrm{pH}$ measuring with a $4 \%(\mathrm{~m} / \mathrm{v})$ agarose gel plug. b) Applying the various cleaning solutions on a pink-orange stain on the object with a cotton swab. c) Deposits extracted from the textile on the blotter paper underneath the test zone. itive and negative). This means that both solutions with a higher and a lower $\mathrm{pH}$ than that of the surface of the textile may be able to dissolve detrimental substances by means of ionisation and chelation [13].

To select appropriate aqueous solutions for testing, it is helpful to know the $\mathrm{pH}$ of the surface to be cleaned. Subsequently, the desired $\mathrm{pH}$ of the cleaning solution can be adjusted with a view to maximize the resolution.
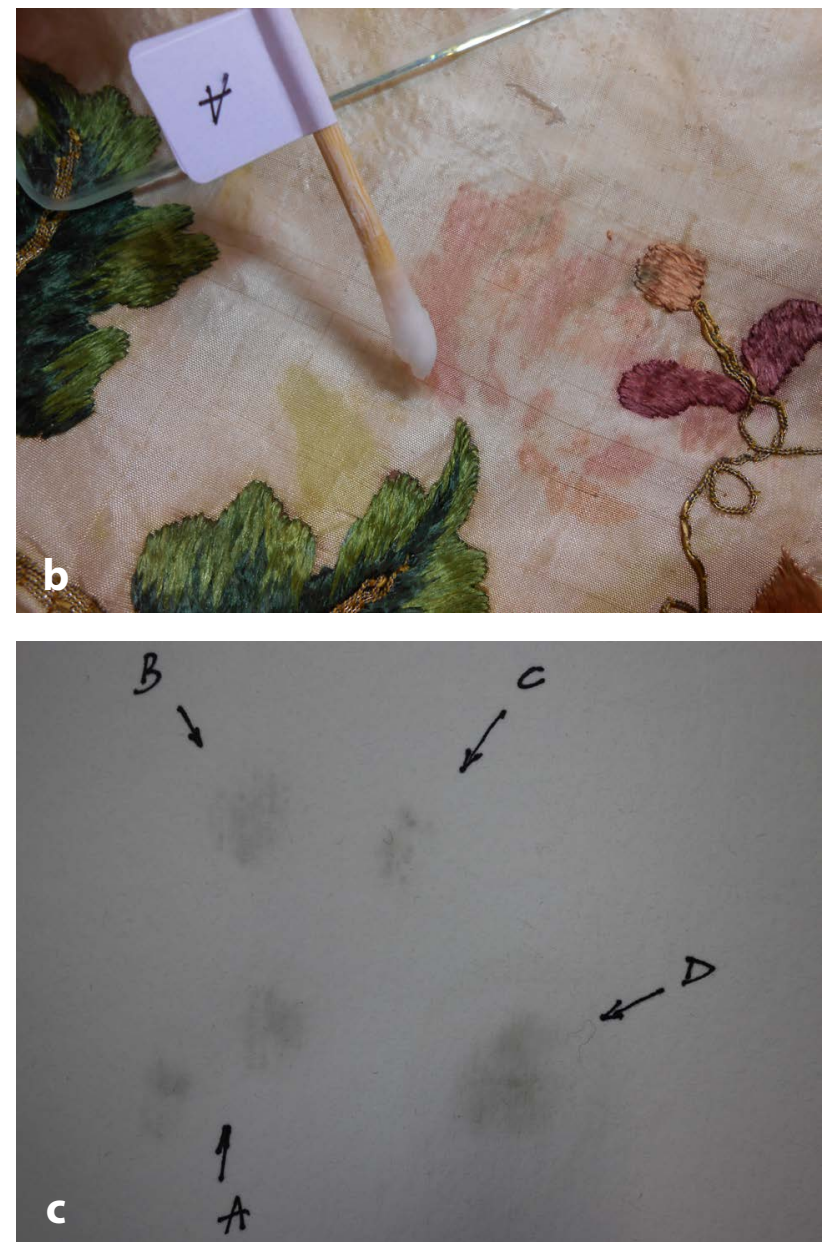
Table 2

Recipes of the cleaning solutions prepared with $\mathrm{pH}$ buffers and chelators

\begin{tabular}{|c|c|c|c|c|c|}
\hline \multirow{2}{*}{ Recipe } & \multicolumn{3}{|c|}{ Component } & \multirow{2}{*}{ pH solution } & \multirow{2}{*}{$\begin{array}{l}\mathrm{pH}, \text { after adjusting with } \\
1 \mathrm{M} \mathrm{NaOH}(40 \mathrm{~g} / \mathrm{l})\end{array}$} \\
\hline & $\mathrm{H}_{2} \mathrm{O}$ & Chelator & Buffer & & \\
\hline A & $100 \mathrm{ml}$ & $0.5 \mathrm{~g}$ citric acid & $0.5 \mathrm{~g}$ boric acid & 2.4 & 8.5 \\
\hline B & $100 \mathrm{ml}$ & $0.5 \mathrm{~g}$ disodium EDTA & $0.5 \mathrm{~g}$ boric acid & 4.5 & 8.5 \\
\hline $\mathrm{C}$ & $100 \mathrm{ml}$ & $1 \mathrm{~g}$ disodium EDTA & & 4.5 & 8.0 \\
\hline $\mathrm{D}$ & $100 \mathrm{ml}$ & 0.5 g DTPA & $0.1 \mathrm{~g}$ acetic acid & 2.5 & 4.5 \\
\hline
\end{tabular}

The surface $\mathrm{pH}$ is also a good indicator for the stability of the silk. Proteins are chemically most stable at their isoelectric region where they are neutrally charged. For conservation purposes the isoelectric region for fibroin in silk is considered between $\mathrm{pH} 3$ and 7. Within this $\mathrm{pH}$ range, the proteins behave electrically neutral and do not attract positively or negatively charged dirt particles, ionic materials or electron-rich polar groups of organic materials. At these $\mathrm{pH}$ values the chance of chemical damage is reduced and the extent of the damage is limited [1]. Therefore, checking the $\mathrm{pH}$ before and after cleaning is one way to measure the safety of the cleaning for the silk.

Despite the limitations of this method, vide infra, measurement of the surface $\mathrm{pH}$ was performed with $4 \%$ $(\mathrm{m} / \mathrm{v})$ agarose plugs, prepared with deionized water, and cut out with a biopsy punch $(\varnothing 4 \mathrm{~mm})$. The plugs where placed in four different locations on the silk ground of the embroidered textile for 10 minutes. Afterwards, the $\mathrm{pH}$ value of the gel blocks was measured with a Horiba LAQUAtwin Compact pH-meter model B-712 (Figure 6a) [17].

The measured values varied between $\mathrm{pH} 6.3$ and 6.5. Due to the minimal differences at the different locations on the textile, it was assumed that the $\mathrm{pH}$ of the entire surface was within the same $\mathrm{pH}$ range.

Based on an average $\mathrm{pH}$ of 6.4 of the surface to be cleaned, test solutions with $2 \mathrm{pH}$ - units above or below the surface $\mathrm{pH}$ were prepared to encourage ionisation, dissociation and chelation of detrimental material (Table 2). In these solutions citric acid, EDTA and DTPA act as chelators for metal ions on the surface. Boric acid in solutions A and B, and acetic acid in solution D, were added as a buffering agents. The solutions were $\mathrm{pH}$ adjusted with $1 \mathrm{M} \mathrm{NaOH}$ to the desired pH. Solution $\mathrm{C}$ was not buffered; in this solution EDTA had a strong chelating effect.

A small amount of each cleaning solution was applied with a cotton swab to a pink-orange stain on the silk ground of the embroidered textile. Blotter paper was placed underneath the textile to absorb the cleaning solution and the dirt particles (Figure 6b).

Visually was established that the cleaning solutions had extracted dirt from the textile. Dark coloured deposits were visible on the blotter paper, but no pink or orange dyes were detected. Colour changes of the stain itself were minimal and showed no visual difference between the different cleaning solutions (Figure $6 \mathrm{c}$ ).

Examining the $\mathrm{pH}$ of the surface after cleaning showed that no $\mathrm{pH}$ change had occurred. The $\mathrm{pH}$ of the surface after application of the different cleaning solutions varied between $\mathrm{pH} 6.2$ and 6.4. It was therefore assumed that the surface $\mathrm{pH}$ of the silk fell within its isoelectric range and that the different cleaning solutions could be regarded as safe for the textile.

Since no differences could be observed visually with regard to the effectiveness of the cleaning solutions, and because none of the cleaning solutions caused measurable $\mathrm{pH}$ changes to the silk ground, the solution with citric acid as chelator and boric acid as $\mathrm{pH}$ buffer was selected for the cleaning.

\section{Treatment in practice}

The cleaning process was initiated with the preparation of the gel. The cleaning solution was prepared by adding $0.5 \mathrm{~g}$ of citric acid and $0.5 \mathrm{~g}$ of boric acid to $100 \mathrm{ml}$ of demineralised water. The $\mathrm{pH}$ of this solution was circa 2.4 . Sodium hydroxide $(1 \mathrm{M} \mathrm{NaOH})$ was added dropwise to raise the $\mathrm{pH}$ of the solution to 8.5 . To $100 \mathrm{ml}$ of this buffered solution, $5 \mathrm{~g}$ of agarose powder was added.

The mixture was heated to $90^{\circ} \mathrm{C}$ in a microwave oven. After approximately 1 minute, the solution was stirred and then further heated for 30 seconds. Before pouring, the mixture was stirred again to prevent the formation of air bubbles in the gel pad. The warm mass was poured onto a glass plate $(15 \mathrm{~cm} \times 30 \mathrm{~cm})$ with raised edges of 2 $\mathrm{mm}$ and levelled with a large spatula. The gelling process during cooling was fast; therefore smoothing the gel should be executed quickly to achieve an even gel pad of $2 \mathrm{~mm}$ thickness.

An area on the object was impregnated with D5, applied economically via pipette to the ground fabric and to the edges of the embroidered regions. The solvent spread easily over the surface and quickly penetrated the textile fibres. After saturation with D5, the surface had a greasy appearance (Figure 7). 


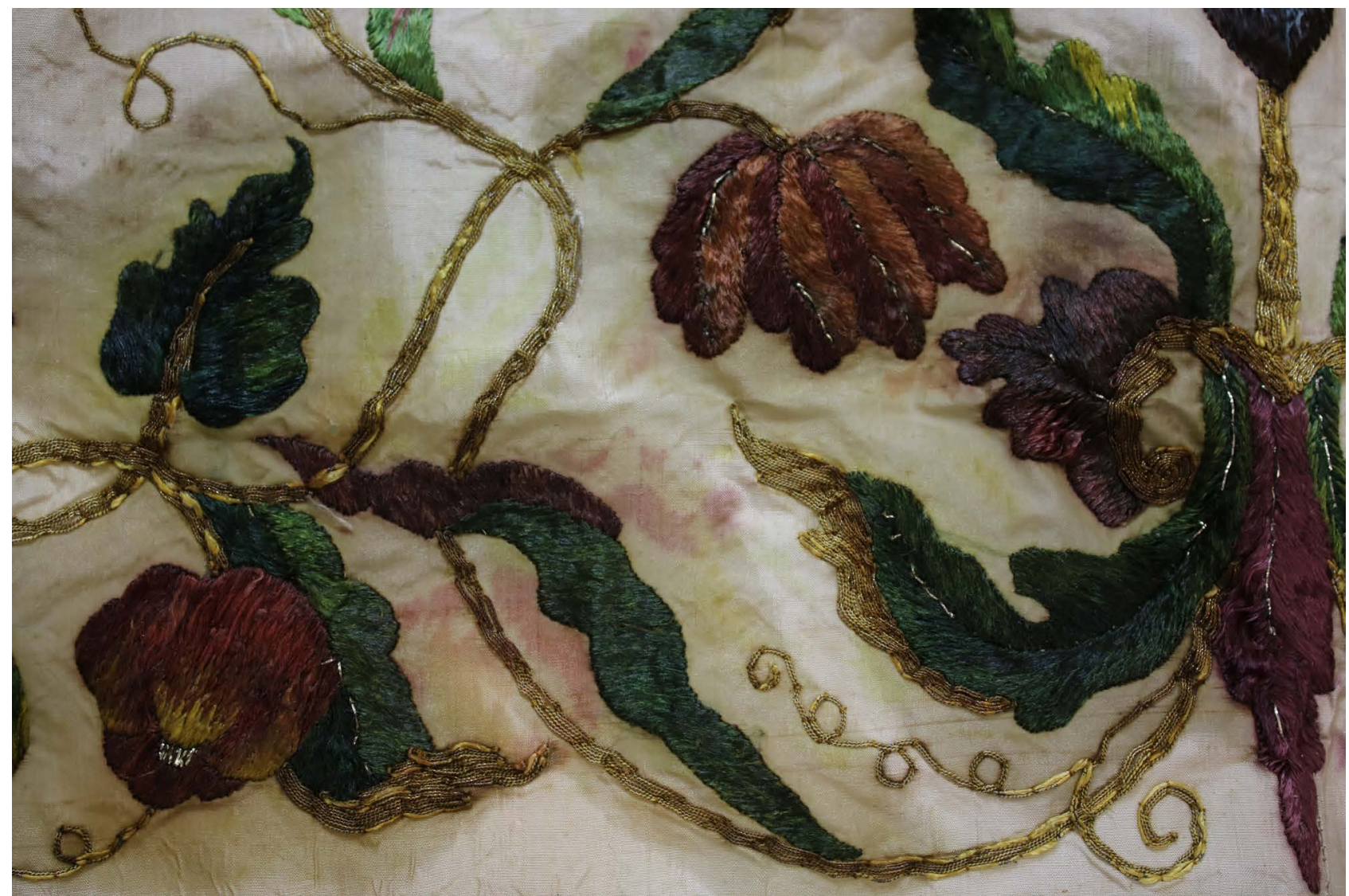

Figure 7. Saturating the silk ground of the object with D5. After application of D5, the surface looked greasy.

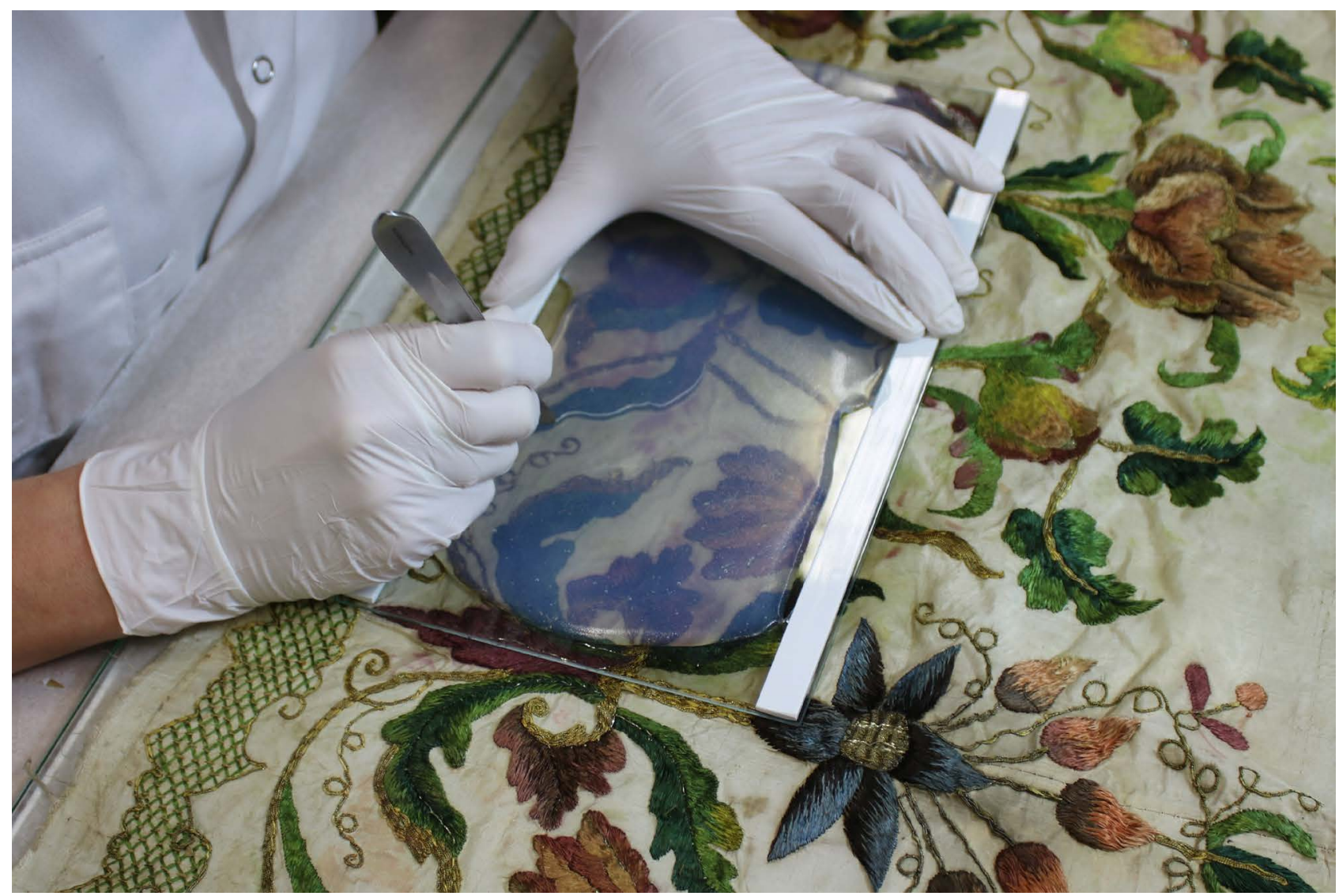

Figure 8. Cutting the agarose gel into shape to fit in between the embroidered areas. 




Figure 9. The agarose gel pads were placed on the silk ground for one hour and covered with glass plates to promote good contact and to delay dehydration of the gel.

The glass plate with the gel was placed on the area to be cleaned. Because the gel was transparent, the required gel shapes were clearly visible and could easily be cut with a scalpel (Figure 8). The pre-cut gel pads were transferred to the ground fabric and covered with glass plates to encourage the contact of the gels with the textile. At the same time, the covering prevented dehydration of the gel pads (Figure 9). The gel pads were left on the textile for approximately 60 minutes, and subsequently removed from the textile and dried [18].

\section{Results}

Visual inspection of the gel pads after removing them from the surface was carried out. A pale yellow to brown discolouration could be observed on most gel pads. Some areas on a few gels were not discoloured, probably in places where contact of the gel with the textile was insufficient. Other discolouration (red, blue, green, etc.) was not observed. Additionally, it was confirmed that bleeding of the dyes of the embroidery threads could be prevented by the application of the cleaning solution in the agarose gel combined with the saturation of the surface with D5.

The discolouration of the silk ground was noticeably diminished after the treatment and the silk regained more shine. No tidelines could be observed after cleaning. The folds and pleats that were present in the textile before cleaning were also flattened.

Most of the stains of dye bleed on the silk ground were reduced. However, they could not completely be removed by this treatment. This may indicate that the cleaning agents dissolved at least partially the components of the dye bleed. Nevertheless, the stains cause less visual disturbance and the aesthetic appearance of the embroidered textile was improved considerably (Figure 10).

\section{Conclusion}

The treatment of the embroidered textile of HotelMuseum Merghelynck was partly successful. The use of an agarose gel, in combination with the saturation of the silk ground of the object with D5 prevented further 
bleeding of the dyes during the cleaning. However, the $5 \%(\mathrm{~m} / \mathrm{v})$ agarose gel was too rigid to achieve an overall even contact with the ground of the embroidered textile, which hindered a homogeneous cleaning process.

Gel pads prepared with lower concentrations of agarose were more flexible and could make better contact with the surface of the textile. However, their larger pores result in a decreased ability to retain the cleaning solution, and cause an over-saturation of the textile. In turn, this caused tidelines. Further research is needed to evaluate whether agarose gels prepared at lower concentrations can be used with a D5 barrier, without contacting the water-sensitive dyes of the embroidery. In addition, the more flexible PVA hydrogels should be examined for their use on textiles [19-20].

None of the selected cleaning solutions containing buffers and chelating agents were able to remove the dye bleed on the silk ground completely. Nevertheless, they could reduce the dye bleed and remove other degradation products from the textile.

The composition of the cleaning solutions was based on the surface $\mathrm{pH}$ of the silk ground to encourage ionization and chelation of detrimental products on the textile. Surface $\mathrm{pH}$ measuring was performed with agarose gel plugs. It should be noted that accuracy of surface $\mathrm{pH}$ measuring by agarose gel plugs has been questioned by more recent research [21]. Consequently, a possible erroneous measurement of the surface $\mathrm{pH}$ may have influenced the effectiveness of the cleaning solutions.

It is likely that characterisation of the dyes may inform the use of different cleaning solutions and eventually lead to better cleaning results. However, due to restrictions in time and budget in the present study, there was no opportunity to analyse each of the many dye colourants present in the textile.

The gel cleaning method described in this study can be considered as an option to clean textiles with bleeding dyes. Further research is necessary to optimize the cleaning method. The lack of tidelines achieved by using D5 during local cleaning, can be regarded as an important advantage and may be of great interest to many textile conservators.

\section{Materials and suppliers}

- Acetic acid, VwR Belgium, https://be.vwr.com/store/

- Agarose LE MDBio, Inc, Gel Strenght $(1 \%) \geq 1200 \mathrm{~g} / \mathrm{cm}^{2}$, EEO 0.1-0.15, Gelling point $(1.5 \%) 33 \pm 1.5^{\circ} \mathrm{C}$, melting point (1.5 \%) $87 \pm 1.5{ }^{\circ} \mathrm{C}$, Gentaur Europe BVBA, https://www. gentaurshop.com/

- Boric acid, citric acid, D4 (octamethylcyclotetrasiloxane) (CAS no. 556-67-2), D5 (decamethylcyclopentasiloxane) (CAS no. 541-02-6), uranine (CAS no. 518-47-8), Kremer Pigmente GmbH \& Co. KG, Germany, https://www.kremerpigmente.com

- DTPA, disodium EDTA, Sigma-Aldrich, Belgium, https:// www.sigmaaldrich.com

- Pongé $10,90 \mathrm{~cm}, 40 \mathrm{~g} / \mathrm{m}$ natural white, Schmidt \& Bleicher GmbH \& Co. KG, Germany, https://www.ideen.com

\section{References}

1 Tímár-Balázsy, Á.; Eastop, D., Chemical Principles of Textile Conservation, Butterworth-Heineman, Oxford (1998) 158, 221-225, 43.

2 Sahmel, K.; Mina, L.; Sutherland, K.; Shibayama. N., 'Removing dye bleed from a sampler: new methods for an old problem', American Institute for Conservation of Historic \& Artistic Works (AIC), Textile Speciality Group Postprints 22 (2012) 78-90.

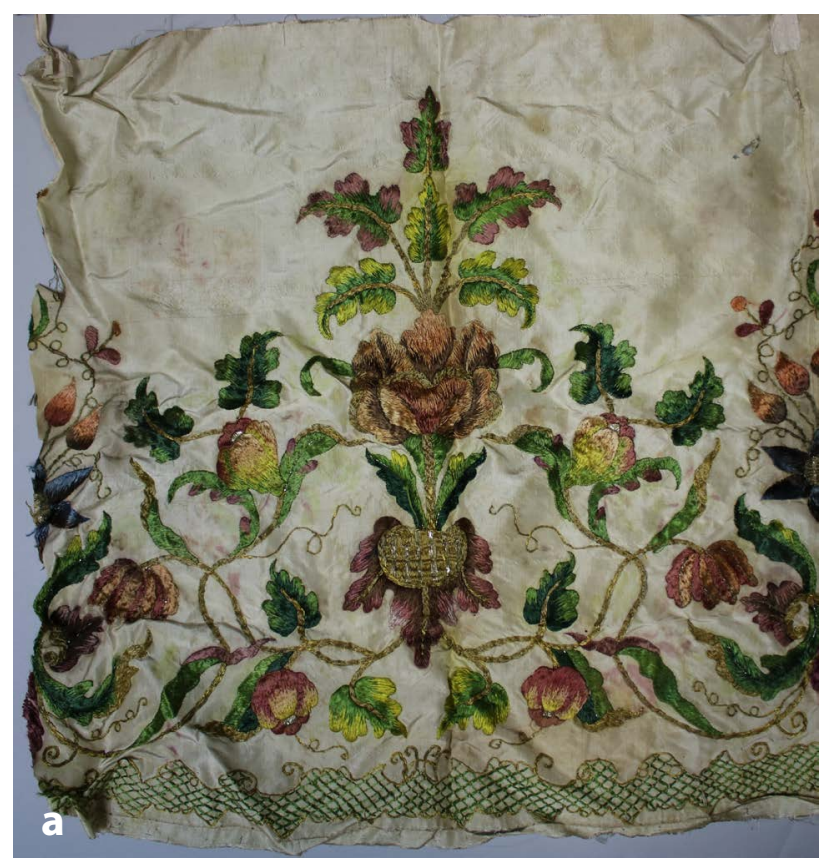

Figure 10. $a$ ) Left side of the embroidered textile before treatment. $b$ ) Right side of the embroidered textile after treatment. 
3 Cremonesi, P., 'Rigid gels and enzyme cleaning', in New Insights into the Cleaning of Paintings, ed. M. F. Mecklenburg, A. E. Charola \& R. J. Koestler, Smithsonian Institution Scholarly Press, Washington (2013) 179-183.

4 Warda, J.; Brückle, I.; Bezúr, A.; Kushel, D., 'Analysis of agarose, carbopol and laponite gel poultices in paper conservation', Journal of the American Institute for Conservation 46 (2007) 263-279, https://doi. org/10.1179/019713607806112260.

5 Scott, C.L., 'The use of agar as a solvent gel in objects conservation', AIC Objects Speciality Group Postprints 19 (2012) 71-83.

6 Schmitt, Emma A., 'An examination of the working properties of agarose gels for textile conservation', MPhil dissertation, University of Glasgow, Glasgow (2014).

7 'Uranine AP (C.I. 45350)', Merck h t t p : / / w w w . merckmillipore.com/BE/fr/product/Uranine-AP-\%28C.I.45350\%29,MDA_CHEM-108462 (accessed 2017-2-17).

8 Stavroudis, C., 'More from CAPS3: surfactants, silicone-based solvents, and microemulsions', WAAC Newsletter 34(3) (2012) 24-27.

9 Benner, J., 'Investigating the potential of decamethylcyclopentasiloxane (D5) as an alternative solvent for textile conservation cleaning', MPhil dissertation, University of Glasgow, Glasgow (2012).

10 Sullivan, M.; Brogdon-Grantham, S.; Taira, K., 'New approaches to cleaning works of art', Winterthur/University of Delaware Program in Art Conservation (2014), http:// resources.conservation-us.org/anagpic-student-papers/ anagpic-2014-student-papers-posters/ (accessed 2019-1-21).

11 'Cyclomethicone 4', in PubChem Compound Database, National Center for Biotechnology Information, CID=11169, https://pubchem.ncbi.nlm.nih.gov/compound/11169 (accessed 2019-1-21).

12 'Cyclomethicone 5', in PubChem Compound Database, National Center for Biotechnology Information CID=10913, https://pubchem.ncbi.nlm.nih.gov/compound/10913 (accessed 2019-1-21).

13 Wolbers, R., personal communication (2017-5-2).

14 Haezendonck, Y.; Bruggemans, K., 'Zuur-basereacties', in Essentiële Elementen Van Chemie - Een Overzicht Van de Fundamenten Van de Scheikunde, Academic and Scientific Publishers, Brussel (2013) 139-162.
15 Stavroudis, C.; Doherty, T.; Wolbers, R., 'A new approach to cleaning I: using mixtures of concentrated stock solutions and a database to arrive at an optimal aqueous cleaning system', WAAC Newsletter 27(2) (2005) 17-28.

16 Cremonesi, P., 'Materials \& methods for surface cleaning and removal of film-forming materials', presentation on a workshop (Maastricht, SRAL, 15-19 February 2016).

17 Stavroudis, C., 'Measuring surface $\mathrm{pH}$ and conductivity using water drop and agarose plug methods' (2013), Getty Conservation Institute, https://www.youtube.com/ watch?v=bOqZEE7Kb8Y (accessed 2019-1-21).

18 Smets, A., 'Gel cleaning in textile conservation - The use of agarose and D5 for cleaning an embroidered textile with bleeding dyes' (2017), https://www.youtube.com/ watch? $=x 9 A 8 k w 6 M s s E \& t=32 \mathrm{~s}$ (accessed 2019-1-21).

19 Domingues, J.; Bonelli, N.; Giorgi, R.; Fratini, E.; Baglioni, P., 'Innovative method for the cleaning of water-sensitive artifacts: synthesis and application of highly retentive chemical hydrogels', International Journal of Conservation Science 4(S1) (2013) 715-722.

20 Mastrangelo, R.; Montis, C.;Bonelli, N.; Tempesti, P.; Baglioni, P., 'Surface cleaning of artworks: structure and dynamics of nanostructured fluids confined in polymeric hydrogel networks', Physical Chemistry Chemical Physics 19(35) (2017) 23762-23772, https://doi.org/10.1039/ C7CP02662E.

21 Hughes, A., 'Measurement of surface pH of paper using agarose gel plugs: a feasibility study', in Gels in the conservation of art, eds. L. V. Angelova, B. Ormsby, J. H. Townsend \& R. Wolbers, Archetype Publications, London (2017) 62-66.

Received: 2018-6-17

Revised: 2018-10-31

Accepted: 2018-11-6

Online: $2019-1-25$

This work is licensed under the Creative Commons Attribution-NonCommercial-NoDerivatives 4.0 International License. To view a copy of this license, visit http://creativecommons.org/licenses/by-nc-nd/4.0/deed.en. 